\title{
ANCIENT WOODLAND PLANT SPECIES IN A LANDSCAPE PARK IN CENTRAL POLAND
}

\author{
JANINA JAKUBOWSKA-GABARA ${ }^{1}$, JÓZEF MITKA ${ }^{2}$ \\ ${ }^{1}$ Department of Geobotany and Plant Ecology, University of Łódź \\ Banacha 12/16, 90-237 Łódź, Poland \\ ${ }^{2}$ Botanical Garden, Institute of Botany, Jagiellonian University \\ Kopernika 27, 31-501 Kraków, Poland \\ e-mail: Jozef.Mitka@ib.uj.edu.pl
}

(Received: May 12, 2006. Accepted: June 6, 2007)

\begin{abstract}
A numerical analysis of the phytosociological relevés from ancient and recent woodland on a mesic forest site in central Poland was carried out. Three groups of forest stands were recognised: planted with Pinus, recent and ancient oak-hornbeam Tilio-Carpinetum. The species of ancient woodland occurred mainly in ancient oak-hornbeam forest stands, however some ferns: Dryopteris carthusiana, D. dilatata and D. filix-mas, and an orchid species Epipactis helleborine, are to be found mainly or exclusively in recent forests. The occurrence of ancient forest species in recent woods may be putatively explained by long-distance wind dispersal or by the thriving in situ in unrecognised small wood patches. Twelve ancient woodland indicators (i.e. $36 \%$ of a total number found in the region under study) occur exclusively in ancient woodland. It underlines the role of passive species protection in the maintenance of the regional species diversity.
\end{abstract}

KEY WORDS: ancient woodland indicators, Braun-Blanquet method, oak-hornbeam Tilio-Carpinetum, passive species protection, plantation forests.

\section{INTRODUCTION}

Cultural landscapes currently occupy most of the landmass of Europe. They have been converted from natural landscapes (wilderness), consisted mainly of forest plant communities, from the Neolithic (Knapp 1998). In central Europe areas of deciduous forests were taken under agriculture, and nowadays they form small and scattered wood complexes among arable fields (Kotańska et al. 2001; Jacquemyn et al. 2003). Some of them are ancient woodland, some are of recent origin. The recent forests have originated in effect of intentional afforestations of previously arable or pasture areas, or in effect of spontaneous succession on abandoned fields, meadows, xerothermic grasslands, and pastures.

In Poland farming and pastoral agriculture affected the vegetation cover for centuries. A great part of recent forests have originated in the result of forestry planting between the I and II World Wars and during the last post-war period. Their area has been continuously increasing in effect of changes in land-use, mainly owing to abandoning of agriculture and afforestation of poor, not suitable for agriculture, soils. Nowadays, the ceasing of cultivation enhances the recent forests formation.

The ecological investigations point to the significant difference in floristic composition between ancient and recent woodland. The tempo of colonisation of the recent woods by forest species is nowadays intensively studied. The studies carried out to the date proved that the colonisation depends on many factors, to mention the distance from the ancient wood (a source area), seed dispersal ability, the time of agriculture use and of regeneration, the age and cover of tree-stand, and soil conditions (Bossuyt et al. 1999; Dzwonko 2001a; McLachlan and Bazely 2001; Verheyen and Hermy 2001). Studies by Bossuyt and Hermy (2000) and Brunet and Oheimb (1998) proved that fairly great number of forest species may colonise the recent woods in time of 70-90 years. It is known that planted tree species significantly, and in many ways, affected soil processes and controlled their chemistry (Augusto et al. 2002). It was showed that the most adverse impact on the vegetation, litter and soil of broad-leaved forests have coniferous trees (Dzwonko 2001a). The dominant tree species controls phytoclimate and in effect determinates significantly the species composition of secondary forests (Dzwonko and Loster 1997).

The role of biological features of plants is also stressed, mainly type of dispersal (Dzwonko and Loster 1988, 1989; Honnay et al. 1998; Hermy et al. 1999). Among ecological factors the isolation of the woodland patches from the source area, the effect of dominant tree species, and the historical reasons in the process of their colonisation by fo- 
rest and non-forest species are stressed (Peterken and Game 1984; Dzwonko and Loster 1997; Bossuyt et al. 1999; Bossuyt and Hermy 2000; Dzwonko 2000a, b; Verheyen et al. 2003).

The aim of the paper is to show the difference in floristic composition between ancient and recent woodland in a partially protected area of a landscape park. This region under study has a relatively large percent of forests in generally cultural landscape of central Poland. The main question concerns the ability of preservation/regeneration of the ancient woodland species in planted with pine and spontaneously regenerated forests on the oak-hornbeam site. We used a "community-approach" method to survey the representative forest stands in partially protected area. The results obtained point to the ecological mechanisms important in the passive protection of ancient woodland species. The knowledge on the dispersal/persistence potential of ancient woodland species in recent woods furnishes information needed for the shaping of recent woodland in more natural appearance (Harmer et al. 2001). We point also to a group of forest species with weak dispersal/persistence potential. Their existence depends solely on the continuous forest history.

\section{MATERIALS AND METHODS}

The investigations were carried out in a landscape park the Bolimów Park Krajobrazowy, one of a few regions in central Poland covered by a relatively large forested area of c. 14000 hectars. The study area is located in the Polish lowlands on an altitude 96-105 m above sea level. More than $30 \%$ of the forested area is covered by recent woodlands that adjoin to ancient woodland (Figs 1 and 2a). The greatest deforestation in this area was in the 19th century. The recent woodland has been created here owing to fore- stry planting since the twenties of the 20th century. The tree-stands of old woodlands in the area under study are 90-110 year-old, and of recent woodlands are 70-75 year-old.

In the field ancient and recent woodlands were recognised. The category "ancient woodland" encompasses the remnants of primeval forests and secondary forests originated before stated arbitrary the threshold date. The date depends on the information found in available historical notes and maps that undoubtedly points to the continuous or discontinuous existence of given forest patches in a given area. All forests originated (planted and/or spontaneous) in previously arable/pasture areas after the threshold date are defined as recent (Dzwonko and Loster 2001). The inspection of a historical cartographic materials revealed that stands of the oak-hornbeam forest Tilio-Carpinetum designated here as "ancient woodland" have existed continuously at least since 1839 , and that they have been under moderate forestry use, including selective felling. Recent woodland occurs in patches of forest stands established after this date on arable land, previously being a forested area.

The field studies were carried out in 1998-2001 using traditional phytosociological method by Braun-Blanquet (1964). The relevés were done in the homogenous mesic, mixed-brodleaved forest stands growing on the same soil substratum, i.e. on moderately wet, brown soils (eutric cambisols) on loamy deposits (Fig. 2b). Vegetation cover was estimated using a combined Braun-Blanquet and percentage scales (Mueller-Dombois and Ellenberg 1974). Plant cover values were transformed using ordinal 1-9 scale (van der Maarel 1979). The relevés, each of $100 \mathrm{~m}^{2}$, were done in old oak-hornbeam (16 relevés), recent oak-hornbeam (18 relevés) and recent planted pine forest (25 relevés) in the representative in terms of field-layer species composition forest stands. The initial number of 258 plant and moss species in the data-set was reduced to 77 by Jan-

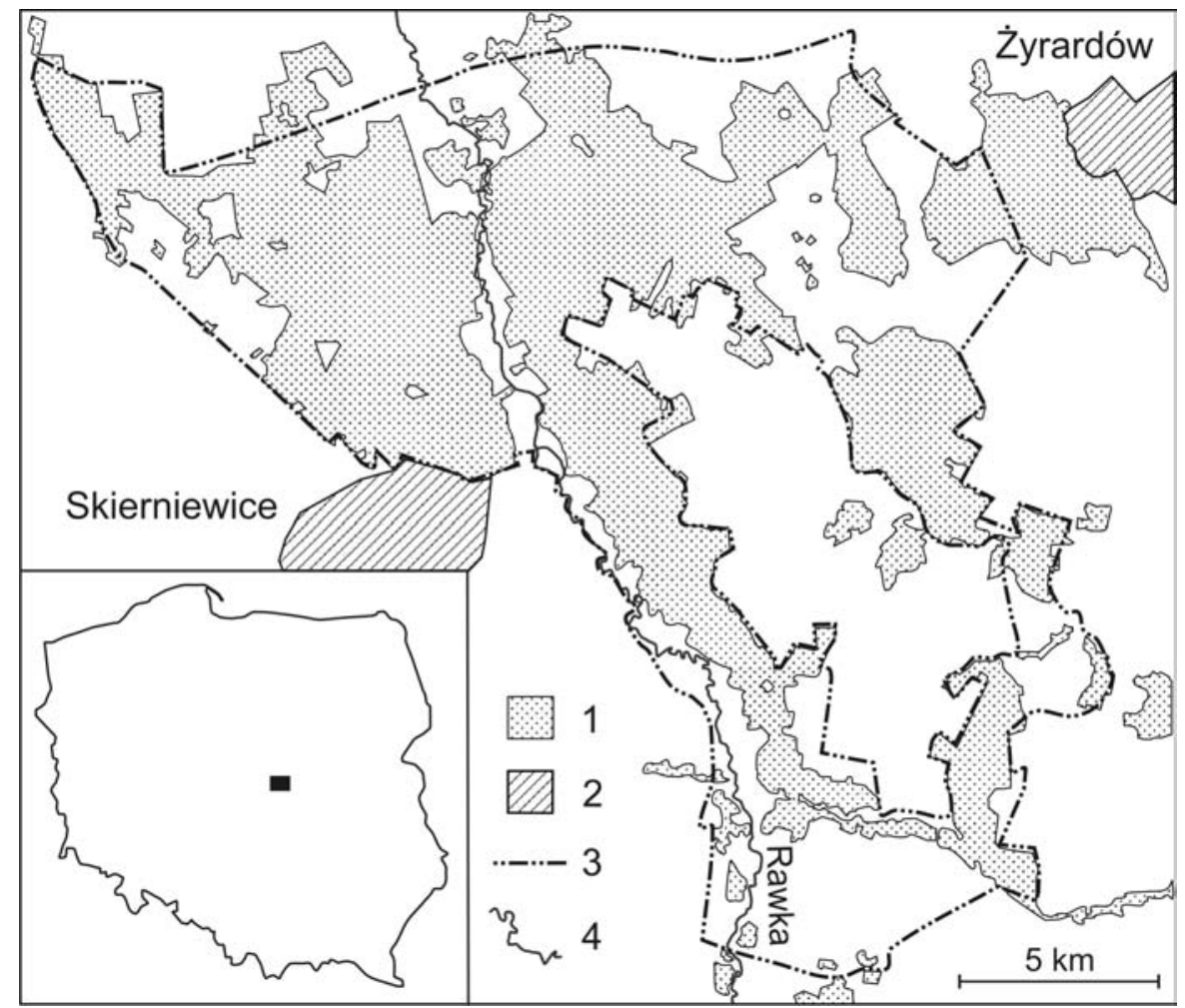

Fig. 1. Localisation of study area in landscape park the Bolimów Park Krajobrazowy. 1 - forests; 2 - town; 3 - boundary of Bolimów Landscape park; 4 - river. 

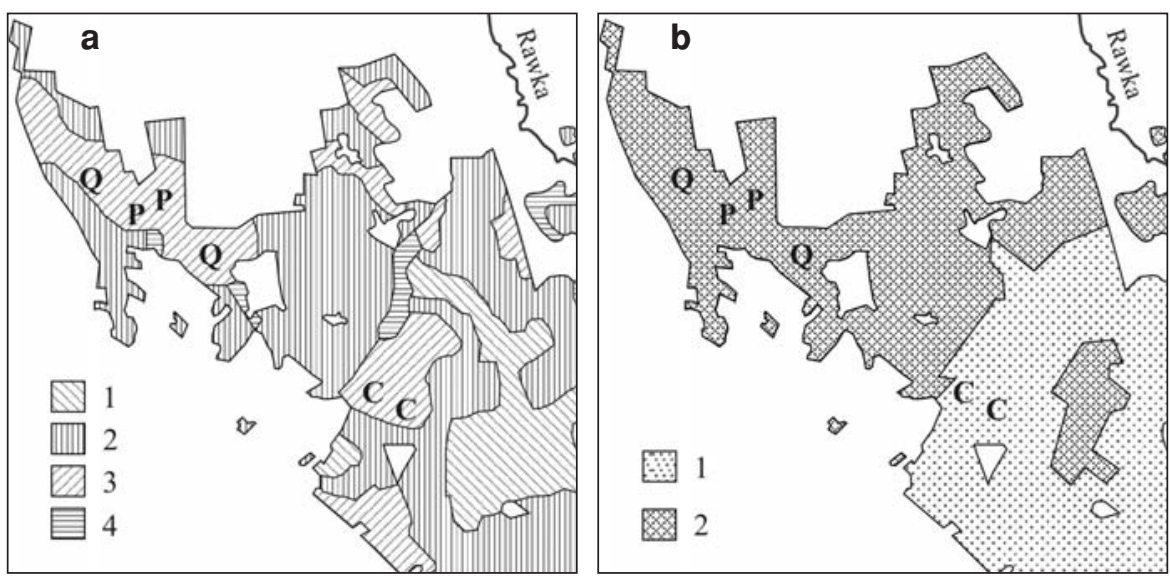

Fig. 2. Localisation of study sites: C - ancient woodland Tilio-Carpinetum; $\mathrm{P}$ - recent woodland with Pinus sylvestris stand; Q - recent woodland with Quercus robur and Betula pendula stand; (a): forest habitat types: 1 fresh coniferous forest; 2 - mixed/coniferous forest; 3 - mixed/broadleaved forest; 4 - alder forest (after map of forest habitat types of Skierniewice Forest Inspectorate); (b): ancient (1) and recent (2) woodlands (on the basis of historical maps from 1839, 1888 and a contemporary map). keys's method (MULVA-5, Wildi and Orlóci 1996) based on the F-test (species with test value $\mathrm{F}<1$ were skipped, leaving ancient forest indicators). They were used for the classification and ordination of relevés (see Fig. 3 and Appendix). From this number, for clarity, only 32 the most informative species were displayed on the diagram (Fig. 3c). However, the statistical analyses based on the initial number of species (see Fig. 3b and Results).

The reduced data-set was classified with the use of a minimal variance (Ward's) clustering (MULVA-5, Wildi and Orlóci 1996) and Euclidean distance measure following the method of Wildi (1989). The ordination of relevés along the first and second axes was carried out with the use of a standard form of a Detrended Correspondence Analysis without downweighting of rare species (CANOCO program, ter Braak 1990). The CANODRAW program was applied for the graphical presentation of the results of ordination (Smilauer 1990).

Nomenclature of plant communities followed Matuszkiewicz (2001), vascular plant species Mirek et al. (2002) and bryophytes Ochyra and Szmajda (1978). Groups of indicator species for ancient woodlands after Hermy et al. (1999) and Dzwonko and Loster (2001).

\section{RESULTS}

A Detrended Correspondence Analysis of relevés enabled the following three groups to be distinguished: an ancient oak-hornbeam woodland Tilio-Carpinetum, a recent forest with planted Scotch pine Pinus sylvestris, and a recent oak-hornbeam forest (Fig. 3a). The first and second DCA axes account for $20 \%$ and $5.5 \%$, respectively.

The ancient oak-hornbeam woodland is characterised by the occurrence of common linden Tilia cordata in the lower $\mathrm{a}_{2}$ tree layer and the highest constancy of planted pedunculate oak Quercus robur in the higher $\mathrm{a}_{1}$ tree layer (Fig. 3c, Appendix). In recent oak-hornbeam forest stands spontaneous silver birch Betula pendula attains the highest coverage. Planted with pine stands are characterised by the constant occurrence of pedunculate oak in lower $\mathrm{a}_{2}$ tree layer.

Each of the groups of forest stands have specific set of species (Fig. 3c, d), and some of them are indicators of ancient woodland; most of them occur in old oak-hornbeam woodland (Table 1). However, some of them have found their optimum in recent oak-hornbeam, as e.g. Epilobium montanum, Geum urbanum, Paris quadrifolia, and an orchid Epipactis helleborine. The percentage of forest spe- cies, especially indicators of ancient woodland, is the lowest in planted with pine stands. Nevertheless, pteridophytes of ancient woodland: Dryopteris carthusiana, D. dilatata, and D. filix-mas, flourish here (Table 1, Appendix).

There is a tendency to increase in the total number of species in the relevés, including trees, shrubs and groundlayer plants (herbaceous and mosses), starting from the planted pine forest, through recent to old oak-hornbeam forest stands (Fig. 3b). However, taking into consideration only herb-layer plants, the highest, and statistically significant $(\mathrm{F}=6.17$, d.f. $=2, \mathrm{p}=0.004$, a posteriori LSD contrasts, STATISTICA software, StatSoft, Inc. 1984-1995), mean number of species per relevé, amounted to $15 \pm 2.7 \mathrm{SD}$, was noted in recent oak-hornbeam forest. In planted with pine and in old oak-hornbeam forests the mean amounted to $12.7 \pm 2.7$ and 11.6 \pm 3.6 , respectively, and was not statistically significant $(\mathrm{p}>0.05)$. The highest number of herbaceous species in recent oak-hornbeam forest was in part due to constant presence here of the Artemisietea class species, as e.g. Chaerophyllum temulum, Geranium robertianum, and Myosoton aquaticum (Fig. 3b).

\section{DISCUSSION}

Generally, in the lowlands of Poland the oak-hornbeam Tilio-Carpinetum woodland (Carpinion) is a climatic-depended forest climax community. In its site after clear-cut or on abandoned arable land a community with silver birch Betula pendula has been regenerated at first. Silver birch attains the highest percentage cover in the secondary oakhornbeam forest (Appendix) and may be often found in other regions of Poland including the lowlands, highlands and the Carpathian foothills (Jakubowska-Gabara 1992; Hereźniak 1993; Stachurska 1998). It undergoes further succession to the climax oak-hornbeam forest.

The ancient and recent woodland of the lowlands in central Poland follow he general picture emerged from the ecological studies carried out in other region of Poland and in western Europe (Peterken and Game 1984; Dzwonko and Loster 1989; Graae and Heskjćr 1997; Honnay et al. 1998; Hermy et al. 1999). Ancient woods are generally richer in plant species (Fig. 3b). However, taking into consideration only herb-layer species, their floristic composition is less differentiated in comparison to recent forests. This is owing to the occurrence in the latter of non-woodland species, mainly of meadow and ruderal sites (Dzwonko and Loster 1988). In present studies the recent woods were cha- 

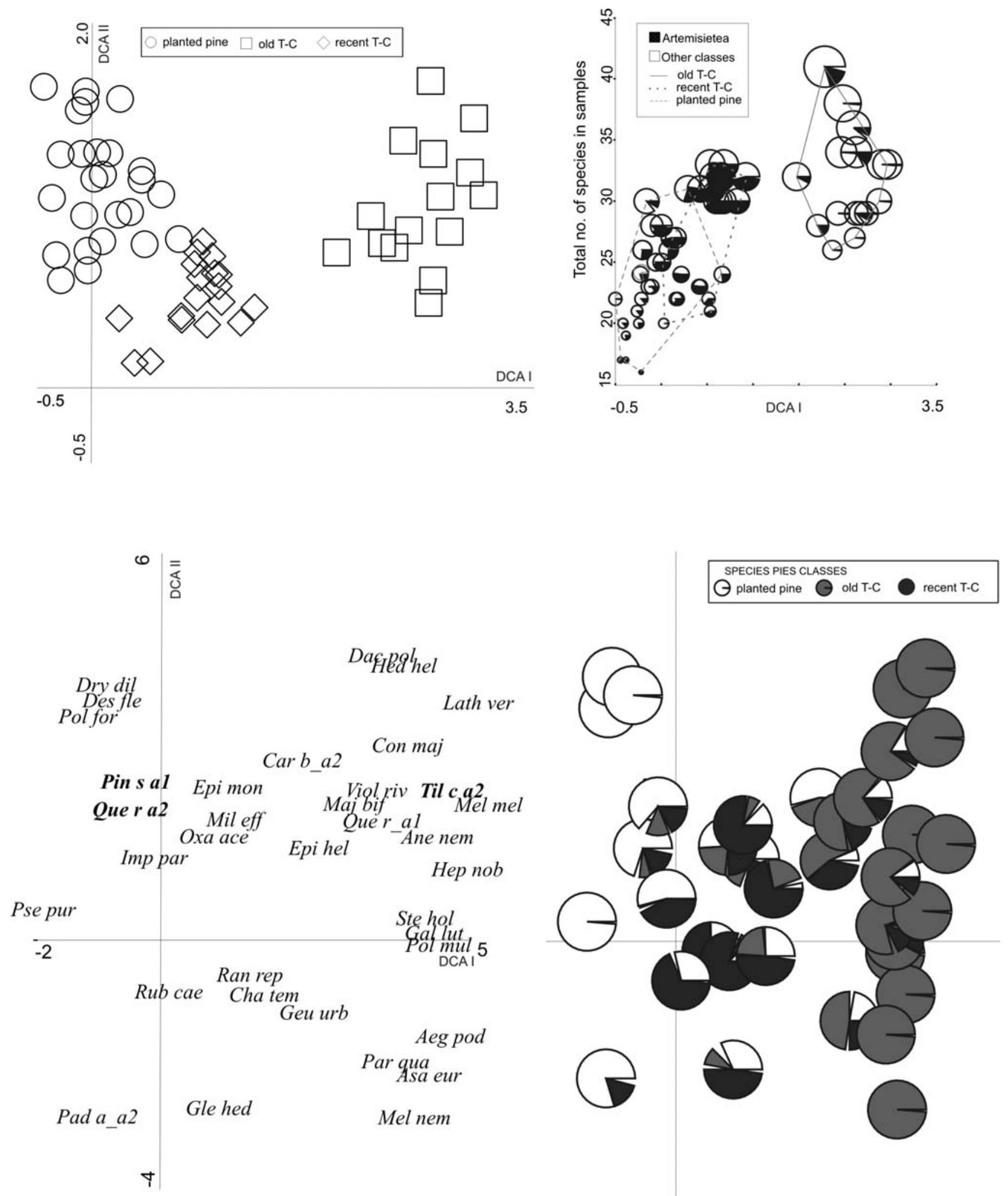

Fig. 3. Ordination of (a) relevés and species (c) found in old Tilio-Carpinetum woodland and recent forest stands with Betula pendula, Pinus sylvestris and Quercus robur along the first two CA axes (some species skipped to clarify the picture, the list of species names in Appendix). Dominant tree species are marked in bold; (b): total number of species (area of a circle proportional to no. of species) and the percentage of the Artemisitea class species in relevés; (d): the percentage occurrence of species (see Fig. 2c) in forest classes: planted with pine, recent and ancient oak-hornbeam Tilio-Carpinetum (T-C) woods.

racterised by the species of the Artemisietea class (Fig. 3d, Appendix).

One of the most striking findings was the occurrence of the ancient woodland indicators (Dzwonko and Loster 2001) in recent forest stands. They form a uniform group taking into consideration their dispersal strategy. Most of them are anemochores, and representatives of auotochores and epizoochores occur scarcely. Anemochores are represented mainly by hovering Drypteris spp. which were much frequent in recent forests, and $D$. dilatata was specific for planted pine forest (Table 1, Appendix). We did not study the ecological mechanism responsible for their constancy 
TABLE 1. Species constancy classes (I - 1-20\%; II - 21-40\%; III - 41-60\%, IV - 61-80\%; V - 81-100\%) of ancient forest indicators in ancient and recent forests in the Bolimów Landscape Park, central Poland.

\begin{tabular}{|c|c|c|c|c|c|c|c|c|}
\hline & $\begin{array}{c}\text { Planted } \\
\text { Pinus forest }\end{array}$ & $\begin{array}{c}\text { Recent } \\
T .-C \text {. forest }\end{array}$ & $\begin{array}{c}\text { Ancient } \\
\text { T.C. forest }\end{array}$ & Life form & Dispersal & $\mathrm{L}$ & $\begin{array}{c}\text { Type } \\
\text { of strategy }\end{array}$ & Syntaxon \\
\hline \multicolumn{9}{|c|}{ Planted Pinus forest } \\
\hline \multicolumn{9}{|l|}{ Frequent } \\
\hline Dryopteris carthusiana & V & II & II & $\mathrm{H}$ & An1 & 5 & SC/CSR & - \\
\hline Oxalis acetosella & V & IV & IV & $\mathrm{G}, \mathrm{H}$ & $\mathrm{Au}$ & 1 & S/CSR & - \\
\hline Milium effusum & V & IV & III & $\mathrm{H}$ & An2 & 4 & S/CSR & $\mathrm{F}$ \\
\hline Dryopteris filix-mas & IV & IV & I & $\mathrm{H}$ & An1 & 3 & $\mathrm{SC}$ & $\mathrm{F}$ \\
\hline \multicolumn{9}{|l|}{ Specific } \\
\hline Dryopteris dilatata & III & - & - & $\mathrm{H}$ & An1 & 4 & SC/CSR & V-P \\
\hline
\end{tabular}

Recent Tilio-Carpinetum

\begin{tabular}{|c|c|c|c|c|c|c|c|c|}
\hline \multicolumn{9}{|l|}{ Frequent } \\
\hline Brachypodium sylvaticum & III & IV & II & $\mathrm{H}$ & Ep & 3 & $\mathrm{~S} / \mathrm{SC}$ & Q-F \\
\hline Epipactis helleborine & - & IV & II & G & An 1 & 3 & S & $\mathrm{F}$ \\
\hline Poa nemoralis & II & IV & III & $\mathrm{H}$ & An2 & 5 & $\mathrm{~S} / \mathrm{CSR}$ & Q-F \\
\hline Epilobium montanum & I & III & I & $\mathrm{H}$ & An2 & 4 & CSR & $\mathrm{F}$ \\
\hline
\end{tabular}

Old Tilio-Carpinetum

\begin{tabular}{|c|c|c|c|c|c|c|c|c|}
\hline \multicolumn{9}{|l|}{ Frequent } \\
\hline Stellaria holostea & $\mathrm{I}$ & $\mathrm{I}$ & V & $\mathrm{C}$ & $\mathrm{B}$ & 5 & CSR & $\mathrm{F}$ \\
\hline Anemone nemorosa & I & I & $\mathrm{V}$ & G & M & $3(\mathrm{Z})$ & S/SR & $\mathrm{F}$ \\
\hline Viola riviniana & $\mathrm{I}$ & I & IV & $\mathrm{H}$ & M & 5 & $\mathrm{~S}$ & - \\
\hline Ajuga reptans & $\mathrm{I}$ & III & $\mathrm{V}$ & $\mathrm{H}$ & M & 6 & CSR & - \\
\hline Scrophularia nodosa & I & III & IV & $\mathrm{H}$ & An1 & 4 & $\mathrm{CR}$ & $\mathrm{F}$ \\
\hline Mycelis muralis & II & III & IV & $\mathrm{H}$ & An2 & 4 & S/CSR & - \\
\hline Convallaria majalis & I & - & III & G & En & 5 & $?$ & - \\
\hline Polygonatum odoratum & $\mathrm{I}$ & - & III & G & En & 7 & $?$ & - \\
\hline Majanthemum bifolium & II & II & V & G & En & 3 & $?$ & - \\
\hline Galeobdolon luteum & - & $\mathrm{I}$ & V & $\mathrm{C}$ & M & 3 & $\mathrm{~S} / \mathrm{SC}$ & $\mathrm{F}$ \\
\hline Viola reichenbachiana & - & $\mathrm{I}$ & IV & $\mathrm{H}$ & M & 4 & $?$ & $\mathrm{~F}$ \\
\hline Adoxa moschatellina & - & $\mathrm{I}$ & I & G & En & 5 & $?$ & $\mathrm{~F}$ \\
\hline \multicolumn{9}{|l|}{ Specific } \\
\hline Polgonatum multiflorum & - & - & IV & G & En & 2 & $?$ & $\mathrm{~F}$ \\
\hline Melica nutans & - & - & IV & $\mathrm{G} / \mathrm{H}$ & M & 4 & $?$ & Q-F \\
\hline Galium schultesii & - & - & IV & G & An2 & 5 & $?$ & $\mathrm{~F}$ \\
\hline Carex digitata & - & - & III & $\mathrm{H}$ & M & 3 & $?$ & Q-F \\
\hline Aegopdium podagraria & - & - & III & $\mathrm{H}$ & B & 5 & $\mathrm{CR} / \mathrm{CSR}$ & Q-F \\
\hline Hepatica nobilis & - & - & II & $\mathrm{H}$ & M & 4 & $?$ & Q-F \\
\hline Dactylis polygama & - & - & II & $\mathrm{H}$ & An2 & 5 & $?$ & $\mathrm{~F}$ \\
\hline Asarum europaeum & - & - & II & $\mathrm{H}$ & M & 3 & $?$ & $\mathrm{~F}$ \\
\hline Lathytrus vernus & - & - & II & G & $\mathrm{Au}$ & 4 & $?$ & $\mathrm{~F}$ \\
\hline Melampyrum nemorosum & - & - & II & $\mathrm{T}$ & M & $3 / 4(Z)$ & $?$ & $\mathrm{~F}$ \\
\hline Melittis melissophyllum & - & - & $\mathrm{I}$ & $\mathrm{H}$ & B & 5 & $?$ & Qp \\
\hline Hedera helix & - & - & I & $\mathrm{Ch}$ & En & 4 & $\mathrm{SC}$ & - \\
\hline
\end{tabular}

Ancient forest indicator and life form according to Dzwonko and Loster 2001.

Life form: $\mathrm{Ch}$ - wooden chamephyte; $\mathrm{C}$ - herbaceous chamephyte; $\mathrm{H}$ - hemikryptophyte; $\mathrm{G}$ - geophyte.

Dispersal: An1 - hovering anemochore; An2 - light or heavy anemochore; Au - autochore; C - barochore; En - endozoochore; M - myrmecochore. L light indicator value according to Ellenberg (1992) or (Z) Zarzycki et. al. 2004.

Type of strategy (according to Grime 1979): SC - stress tolerant - competitive; CR - competitive - ruderal; SR - stress tolerant-ruderal; S - stress tolerant; CSR - intermediate. Syntaxonomy: F - Fagetalia; V-P - Vaccinio-Piceetea; Q-F - Querco-Fagetea; Qp - Quercetalia pubescentis (Matuszkiewicz 2001).

in recent forests, but it seems reasonable to postulate their efficient colonisation due to long-distance diaspore transport or in situ persistence ability. Similarly, Dzwonko and Loster (1992) identified D. carthusiana in the secondary woodland near Kraków in the Carpathian Foothills. Also, Falkengren-Grerup and Tyler (1991) found increased mean number of fern species under far-reaching thinning in beech forest in southern Sweden, but D. carthusiana they classified to the group without distinct changes. On the other hand, the results by Hermy et al. (1993), and by Hon- nay et al. (1998) show that D. carthusiana is an indicator of ancient woodland in Belgium. The more frequent occurrence of a hovering anemochore, Epipactis helleborine in recent, than in old stands of the oak-hornbeam forest, is also worth of mention. This orchid is an interesting example of a spreading species on some post-industrial sites in Poland (Cohn et al. 2001).

Grass species: Brachypodium sylvaticum, Milium effusum and Poa nemoralis, generally being considered as indicators of ancient woodland (Dzwonko and Loster 2001), in 
Poland (present study and Stachurska 1998) and in southern Sweden (Falkengren-Grerup and Tyler 1991) are to be found in a great frequency in recent forests. In southern Poland M. effusum grows most often on fresh and moist soils, with their $\mathrm{pH}$ ranging from (3.5) 4.0 to 6.0 (7.0). Its abundance is linearly related to the percentage of nitrogen is mineral-humus soil layer; also it flourishes in thinned stands with canopy cover less then $65 \%$, in comparison to canopy cover 80-95\% (Towpasz and Kotańska 1983). Grass species believed as indicators of ancient woodland, recorded in this study more frequently in recent woods, belong to the group of S/SC - S/CSR ecological strategy (stress tolerant/stress tolerant-competitors-stress tolerant/intermediate) according to Grime's classification (see Dzwonko and Loster 2001). Other grass species, indicators of ancient woodland Dactylis polygama and Melica nutans, occurred exclusively in ancient oak-hornbeam forest. There is not known their ecological strategy according to Grime's classification. D. polygama is an anemochore, and $M$. nutans is a myrmecochore species.

Some typical forest species, especially the indicators of ancient woodland, have low colonisation rate hampered by dispersal and recruitment constraints. Of importance is also the time-spatial isolation (Verheyen and Hermy 2001). The presence of forest species in isolated wood complexes depends on their area, age and contacts with other wood fragments (Jacquemyn et al. 2003). The restoration of the complete floristic composition of the herb-layer in recent woods is a longterm process, might have taken hundred years, even in the case of the domination of a hardwood species and spatial contact with other ancient woodlands (Bossuyt and Hermy 2000; Dzwonko 2001b; Dzwonko and Loster 2001).

In short, in recent Quercus-Betula stands two types of indicator species of ancient woodland occur: hovering anemochores (mainly ferns and one orchid species) and stress tolerant - mainly grasses. Their occurrence here may be explained by their life strategies enabling them to colonise recent woods or they may persist in situ. There is no clear, based on the historical material at hand, whether it is a result of their continuity or long-distance dispersal. It is likely that they might persist in non-woodland communities (Wulf 2004). To a list of species have persisted on former arable fields, and then afforested with Quercus robur and Pinus sylvestris, the author includes both grass and fern species of interest. The occurrence of Epipactis helleborine in recent woods is probably more attributable to its colonisation than to persistence ability. Also, in the case of pteridophytes short-distance colonisation from unrecognised forest remnant patches or long-distance dispersal seems the most relevant.

Dzwonko (2001a) showed that the most adverse impact on the vegetation, litter and soil of broad-leaved forest have coniferous trees. The results of the present paper confirm it completely. In forest stands with the domination of Pinus sylvestris, the smallest mean number of species per releve was recorded, and those inhabiting them had moderate-low (with some exceptions as e.g. Sorbus aucuparia, Amelanchier spicata, Dryopteris dilatata and acidophilous mosses) constancy values (Appendix). It means that the stands with Pinus were the most unstable in their species composition.

Summing up, the total number of species in ancient woods in the landscape park Bolimów Park Krajobrazowy is differentiated and generally greater than in the respective recent woodland. It is a result of the complex structure of the ancient woods. On the other hand, the number of herblayer species is the highest in recent oak-hornbeam forest due to constant presence of the Artemisitea class species. In recent woods a smaller number of species occur, in this indicators of ancient woodland. The recent woods with planted pine differed in species composition from the ancient, broad-leaved woods on the respective site. Ancient woodland has a specific group of herb-layer species with low persitence/colonistation potential (Fig. 3c, Appendix). It seems that their re-establishment in recent forest stands is hardly to accomplish. Their preservation in a cultural landscape relies mainly on the uninterrupted continuity of forest patches in the ecological time-scale.

\section{ACKNOWLEDGEMENTS}

We thank Zbigniew Dzwonko and the anonymous referee for valuable comments on the manuscript.

\section{LITERATURE CITED}

AUGUSTO L., RANGER J., BINKLEY D., ROTHE A. 2002. Impact of several common tree species of European temperate forests on soil fertility. Ann. For. Sci. 59: 233-253.

BOSSUYT B., HERMY M. 2000. Restoration of the understorey layer of recent forest bordering ancient forest. Appl. Veg. Sci. 3: 43-50.

BOSSUYT B., HERMY M., DECKERS J. 1999. Migration of herbaceous plant species across ancient-recent forest ecotones in central Belgium. J. Ecol. 87: 628-638.

BRAUN-BLANQUET J. 1964. Pflanzensoziologie. Springer Verlag. Vien.

BRUNET J., VON OHEIMB G. 1998. Migration of vascular plants to secondary woodlands in southern Sweden. J. Ecol. 86: 429-438.

COHN E.V.J., ROSTAŃSKI A., TOKARSKA-GUZIK B., TRUEMAN I.C., WOŹNIAK G. 2001. The flora and vegetation of an old Solvay process tip in Jaworzno (Upper Silesia, Poland). Acta Soc. Bot. Pol. 70: 47-60.

DZWONKO Z. 2001a. Effect of proximity to ancient deciduous woodland on restoration of the field layer vegetation in a pine plantation. Ecography 24: 198-204.

DZWONKO Z. 2001b. Migration of vascular plants species to a recent wood adjoining ancient woodland. Acta Soc. Bot. Pol. 70: 71-77.

DZWONKO Z., LOSTER S. 1988. Species richness of small woodlands on the Western Carpathian foothills. Vegetatio 76: 15-27.

DZWONKO Z., LOSTER S. 1989. Distribution of vascular plant species in small woodlands on the Western Carpatian foothills. Oikos 56: 77-86.

DZWONKO Z., LOSTER S. 1992. Species richness and seed dispersal to secondary woods in Southern Poland. J. Biogeogr. 19: 195-204.

DZWONKO Z., LOSTER S. 1997. Effects of dominant trees and anthropogenic disturbances on species richness and floristic composition of secondary communities in southern Poland. J. Appl. Ecol. 34: 861-870.

DZWONKO Z., LOSTER S. 2001. Ancient woodland plant species indicators and their importance for nature conservation and vegetation mapping. Prace Geogr. 178: 119-132. (in Polish with English summary)

ELLENBERG H. 1992. Zeigerwerte der Gefäßpflanzen (ohne Rubus). Scripta Geobot. 18: 9-166. 
FALKENGREN-GRERUP U., TYLER G. 1991. Dynamic floristic changes of Swedish beech forest in relation to soil acidity and stand management. Vegetatio 95: 149-158.

GRIME J.P. 1979. Plant strategies and vegetation processes. Wiley \& Sons, Chichester.

GRAAE B.J., SUNDE P.B. 2000. The impact of forest continuity and management on forest floor vegetation evaluated by species traits. Ecography 23: 720-731.

HEREŹNIAK J. 1993. The variability and changes of forest vegetation in the northern part of the Silesia-Cracow Upland. Monogr. Bot. 75: 3-368. (in Polish with English summary)

HARMER R., PETERKEN G., KERR G., POULTON P. 2001. Vegetation changes during 100 years of development of two secondary woodlands on abandoned arable land. Biol. Conserv. 101: 291-304.

HERMY M., VAN DEN BREMT P., TACK G. 1993. Effects of the site history on woodland vegetation. In: Broekmeyer M.E.A., Vos W., Koop H. (ed.), European forest reserves. Pudoc Scientific Publishers, Wageningen, pp. 219-232.

HERMY M., HONNAY O., FIRBANK L., GRASHOF-BOKDAM C., LAWESSON J.E. 1999. An ecological comparison between ancient and other forest plant species of Europe, and the implications for forest conservation. Biol. Conserv. 91: 9-22.

HONNAY O., DEGROOTE B., HERMY M. 1998. Ancient-forest plant species in Western Belgium: a species list and possible ecological mechanisms. Belg. J. Bot. 130: 139-154.

JACQUEMYN H., BUTAYE J., HERMY M. 2003. Influence of environmental and spatial variables on regional distribution of forest plant species in a fragmented and changing landscape. Ecography 26 (6): 768-770.

JAKUBOWSKA-GABARA J. 1992. Natural and anthropogenic differentiation of forest communities of south-easten part of Nizina Południowopolska region. Badania Fizjograficzne nad Polską Zachodnią. Ser. B 41: 175-198. (in Polish with English summary)

KNAPP H.D. 1998. Natural vegetation regions and cultural landscapes of Europe. In: S. Dömpke, M. Succow (ed.) - Cultural landscapes and nature conservation in Northern Eurasia - Proceedings of the Wörlitz Symposium, March 20-23, 1998, Naturschutzbund Deutschland (NABU) e.v., Bonn, pp. 86-94.

KOTAŃSKA M., TOWPASZ K., TRZCIŃSKA-TACIK H., MITKA J. 2001. Vegetation cover in an ancient agricultural landscape: the Proszowice Plateau (Southern Poland) as a case study. Acta Soc. Bot. Pol. 70: 313-322.

MCLACHAN S., BAZELY D.R. 2001. Recovery patterns of understory herbs and their use as indicators of deciduous forest regeneration. Conserv. Biol. 15, 1: 98-110.

MATUSZKIEWICZ W. 2001. Przewodnik do oznaczania zbiorowisk leśnych Polski [The key for determination of Polish fo- rest communities]. Państwowe Wydawnictwo Naukowe, Warszawa. (in Polish)

MIREK Z., PIĘKOŚ-MIRKOWA H., ZAJAC A., ZAJAC M. 1995. Vascular plants of Poland. A checklist. Polish Botanical Studies, Guidebook Series 15: 3-303.

MUELLER-DOMBOIS D., ELLENBERG H. 1974. Aims and Methods of Vegetation Ecology. Wiley, New York.

OCHYRA R., SZMAJDA P. 1978. An annotated list of Polish mosses. Fragm. Flor. Geobot. 24: 93-145.

PETERKEN G.F., GAME M. 1984. Historical factors affecting the number and distribution of vascular plant species in the woodlands of central Lincolnshire. J. Ecol.: 155-182.

SMILAUER P. 1990. CANODRAW. Scientia Publishing. Budapest.

STACHURSKA A. 1998. Forest communities and their transformations in the marginal zone of the Carpathian Foothills. In: W. Chełmicki (ed.), The Carpathian Foothills marginal zone. Man and environment. Prace Geogr. 103: 179-188.

StatSoSoft, Inc. 1984-1995. STATISTICA for WINDOWS. StatSoft, Inc. Tulsa

TER BRAAK C.J.F. 1990. Update notes: CANOCO version 3.1. Agricultural Mathematics Group, Wageningen.

TOWPASZ K., KOTAŃSKA M. 1983. Structure and dynamics of populations of Milium effusum L. in a forest near Polanka Haller in the Wielickie Foothills (southern Poland). Zesz. Nauk. UJ, Prace Bot. 11: 109-142. (in Polish with English summary)

VAN DER MAAREL E. 1979. Transformation of cover-abundance values in phytosociology and its effects on community similarity. Vegetatio 39: 97-114.

VERHEYEN K., HERMY M. 2001. The relative importance of dispersal limitation of vascular plants in secondary forest succession in Muizen Forest, Belgium. J. Ecol. 89: 829-840.

VERHEYEN K., BOSSUYT B., HONNAY O., HERMY M. 2003. Herbaceous plant community structure of ancient and recent forests in two contrasting forest types. Basic Appl. Ecol. 4: 537-546.

WILDI O. 1989. A new numerical solution to traditional phytosociological tabular classification. Vegetatio 81: 95-106.

WILDI O., ORLÓCI L. 1996. Numerical exploration of community patterns. A guide to the use of MULVA-5. $2^{\text {nd }}$ edition. SPB Academic Publishing, The Hague.

WULF M. 2004. Plant species richness of afforestations with different former use and habitat continuity. For. Ecol. Manage. 195: 191-204.

ZARZYCKI K., TRZCIŃSKA-TACIK H., RÓŻAŃSKI W., SZELĄG Z., WOEEK J., KORZENIAK U. 2002. Ecological Indicator Values of Vascular Plants of Poland. W. Szafer Institute of Botany, Polish Academy of Sciences, Kraków. 


\section{APPENDIX}

Species composition and cover values (1-9) of relevés in forest stands of the Bolimów Landscape Park.

Syntaxonomy following Matuszkiewicz (2001) and ancient forest species following Dzwonko and Loster (2001).

Species abbreviations used in Figure 3c.

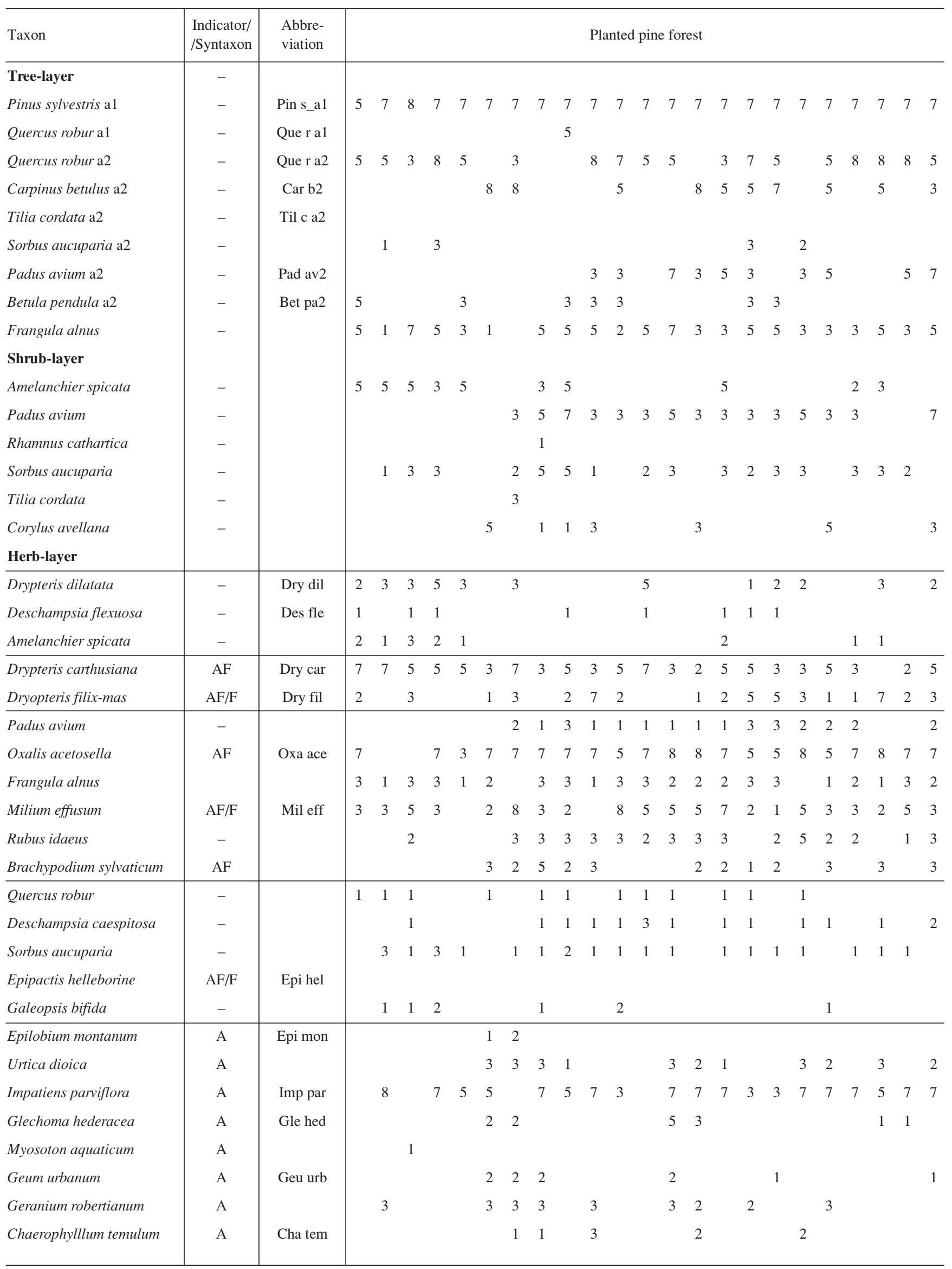




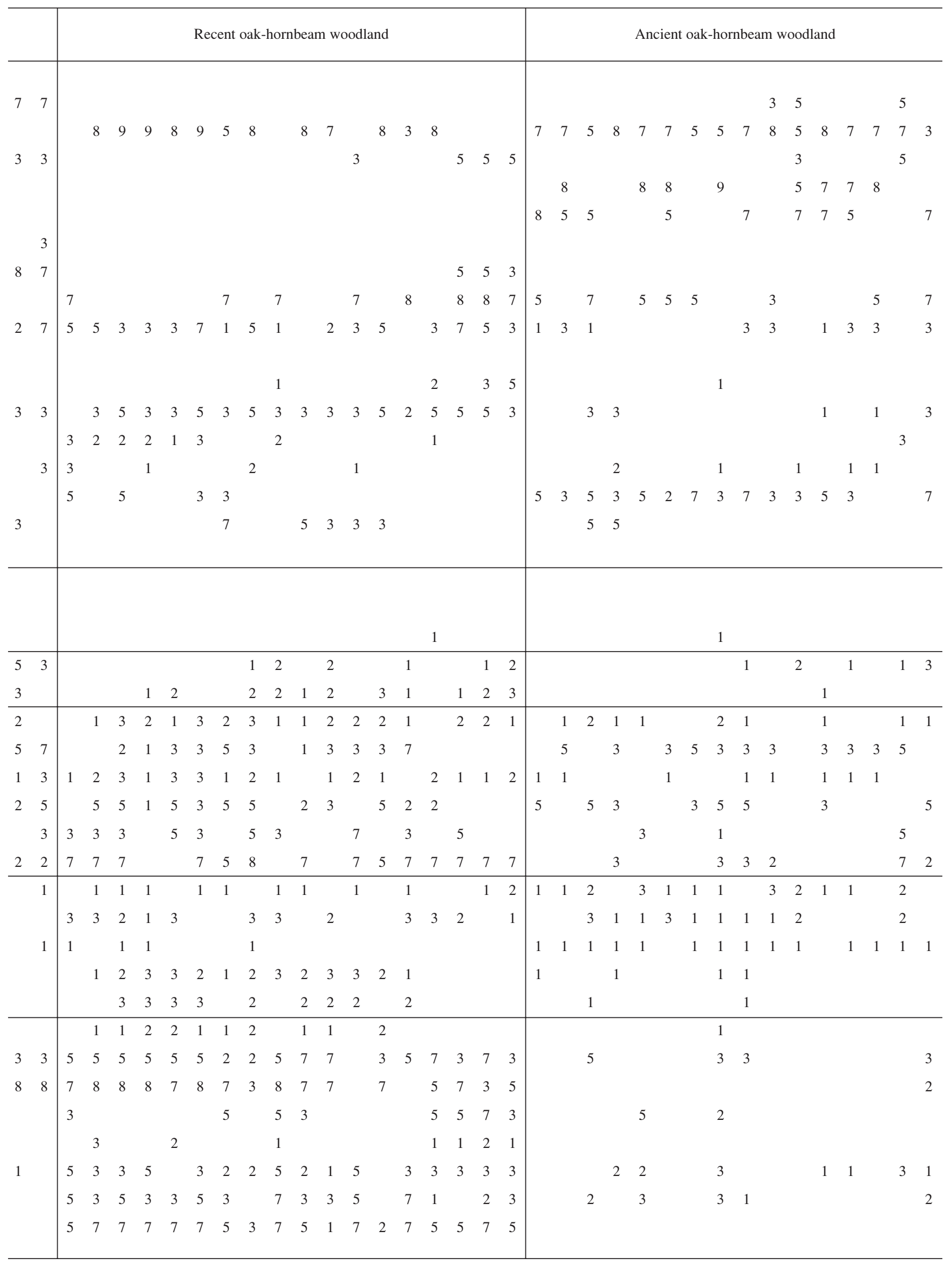




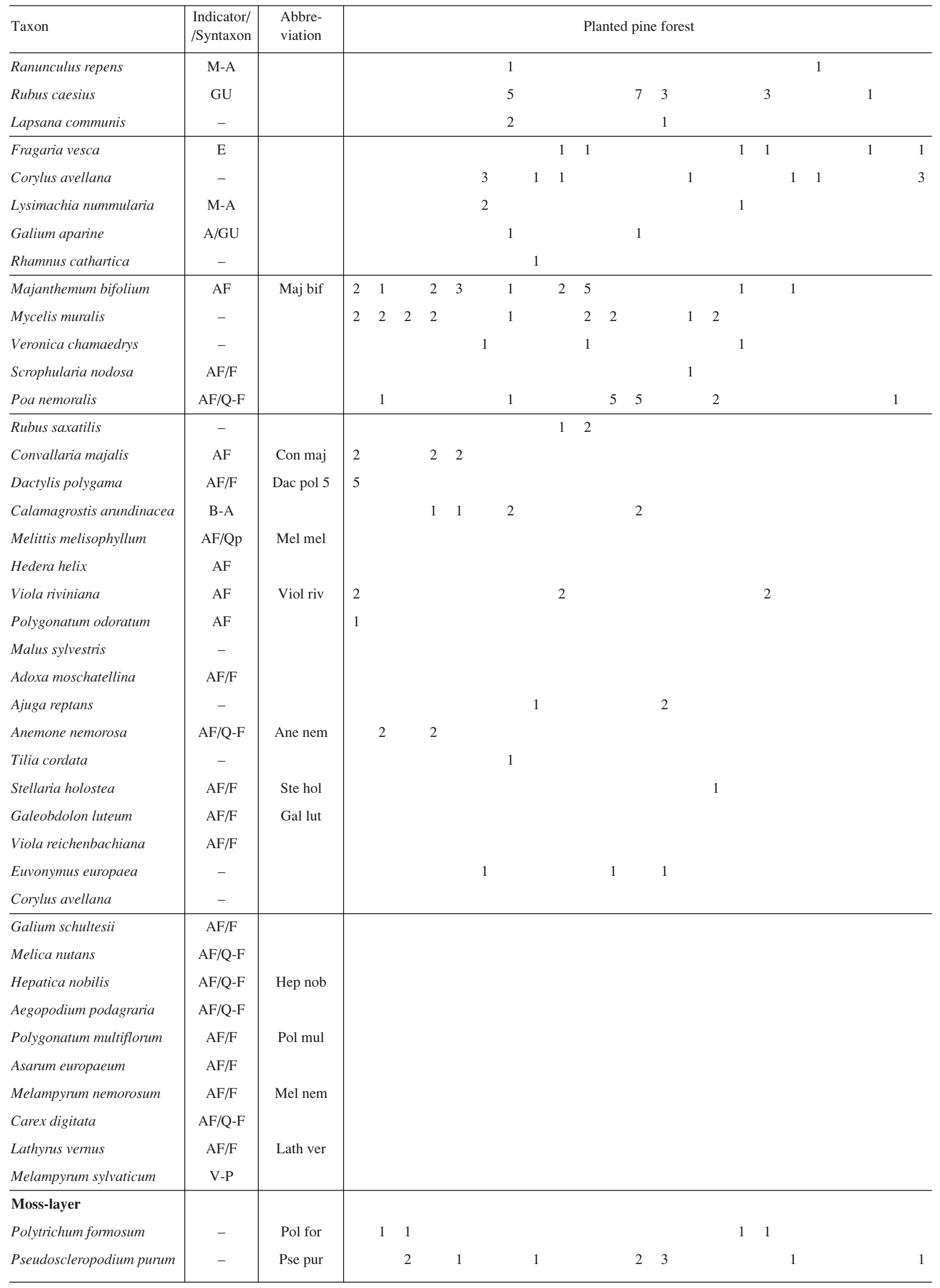




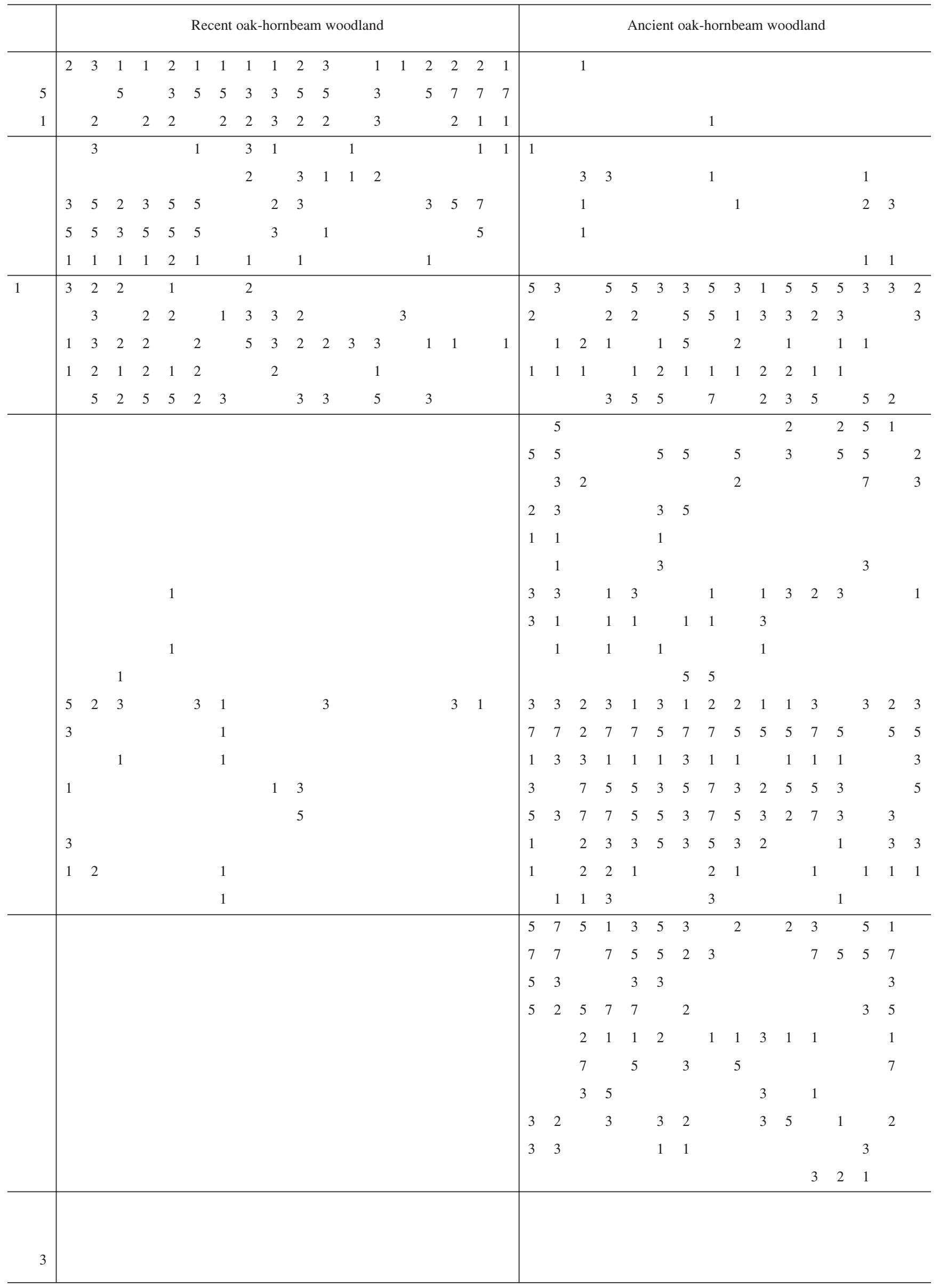

A - Artemisietea; AF - ancient forest indicator (see Table 1); E - Epilobietea angustifolii; F - Fagetalia; B-A - Betulo-Adenostyletea; GU - Galio-Urticenea; M-A - Molinio-Arrenatheretea; Q-F - Querco-Fagetea; Qp - Quercetalia pubescentis; V-P - Vaccinio-Piceetea 